UDC 616.344

\title{
A CLINICAL CASE OF CROHN'S DISEASE
}

\author{
Bohun N. Yu. ${ }^{1,2}$, Kushnir I. E. ${ }^{3}$, Chernyak A. M. ${ }^{3}$, Belal S. ${ }^{4}$ \\ ${ }^{1}$ V. N. Karazin Kharkiv National University, Kharkiv, Ukraine \\ ${ }^{2}$ Kharkiv municipal hospital No. 3, Kharkiv, Ukraine \\ ${ }^{3}$ Government institution «L. T. Malaya Therapy National Institute of the National Academy of medical \\ science of Ukraine», Kharkiv, Ukraine \\ ${ }^{4}$ Asklepios Westklinikum Hamburg, Hamburg, Germany
}

The article demonstrates a clinical case of Crohn's disease. The clinical manifestation of the disease, a diagnostic approach based on laboratory and instrumental methods with discussion of obtained results, and the up-to-date methods of investigation based on the literature data are shown. The significance of lifestyle modification, optimal drug treatment and regular check-ups for improvement of prognosis is emphasized.

KEY WORDS: Crohn's disease, inflammatory bowel disease, clinical case

\section{КЛІНІЧНИЙ ВИПАДОК ХВОРОБИ КРОНА}

\author{
Богун Н. Ю. ${ }^{1,2}$, Кушнір I. Е., ${ }^{3}$, Черняк А. М. ${ }^{3}$, Бєлал $C_{.}^{4}$ \\ ${ }^{1}$ Харківський національний університет імені В. Н. Каразіна, м. Харків, Україна \\ ${ }^{2}$ Харківська міська лікарня № 3, м. Харків, Україна \\ ${ }^{3}$ Державна установа «Національний інститут терапії імені Л. Т. Малої Національної академії \\ медичних наук України», м. Харків, Україна \\ ${ }^{4}$ Асклєпіос Вестклінікум Гамбург, Гамбург, Німеччина
}

В статті наведено клінічний випадок хвороби Крона. Показані клінічні прояви захворювання, підхід до діагнозу на підставі лабораторних та інструментальних методів обстеження з обговоренням отриманих результатів та сучасні методи діагностики на підставі даних літератури. Підкреслюється важливість модифікації образу життя, оптимальної медикаментозної терапії та регулярного спостереження за хворим для покращення прогнозу.

КЛЮЧОВІ СЛОВА: хвороба Крона, запальні хвороби кишечнику, клінічний випадок

\section{КЛИНИЧЕСКИЙ СЛУЧАЙ БОЛЕЗНИ КРОНА}

\author{
Богун Н. Ю. ${ }^{1,2}$, Кушнир И. Э., ${ }^{3}$, Черняк А. Н. ${ }^{3}$, Белал C. $^{4}$ \\ ${ }^{1}$ Харьковский национальный университет имени В. Н. Каразина, г. Харьков, Украина \\ ${ }^{2}$ Харьковская городская больница № 3, г. Харьков, Украина \\ ${ }^{3}$ Государственное учреждение «Национальный институт терапии имени Л. Т. Малой \\ Национальной академии медицинских наук Украины», г. Харьков, Украина \\ ${ }^{4}$ Асклепиос Вестклиникум Гамбург, Гамбург, Германия
}

В статье приведен клинический случай болезни Крона. Показаны клинические проявления заболевания, подход к диагнозу на основании лабораторных и инструментальных методов обследования с обсуждением полученных результатов и современные методы диагностики на основании данных литературы. Подчеркивается важность модификации образа жизни, оптимальной медикаментозной терапии и регулярного наблюдения за больным для улучшения прогноза.

КЛЮЧЕВЫЕ СЛОВА: болезнь Крона, воспалительные заболевания кишечника, клинический случай

\section{INTRODUCTION}

Crohn's disease (CD) is a kind of the inflammatory bowel disease (IBD).It is an idiopathic chronic process which affects any section of digestive tract and is characterized by inflammation of the lining of the gastrointestinal (GI) tract. The other form of 
IBD is called ulcerative colitis (UC), which can cause identical symptoms and is sometimes mistaken for $\mathrm{CD}$. While $\mathrm{UC}$ is limited to the mucosal layer of the colon, $\mathrm{CD}$ can affect any segment of the GI tract from mouth to anus and is characterized by focal, asymmetric, transmural, and, occasionally, granulomatous inflammation. One of the considerable distinguishing features between $\mathrm{CD}$ and UC is that CD can also affect eyes, spine, skin and joints. The most prevalent localization of affection of the GI tract in CD is ileum and colon. CD can often be confused with other conditions such as irritable bowel syndrome, food poisoning, an upset stomach, or an allergy. Early detection and diagnosis can help to avoid severe complications and allow early initiation of treatment. Diagnosis is therefore based on the clinical presentation, physical examination, laboratory and imaging tests (e.g., MRI), endoscopy, and serological testing [1].

\section{CLINICAL CASE}

A 54-year old man was admitted to the Institute of Therapy with complaints of diarrhea for 10-15 times per day with blood and mucus mainly at night, fatigue, abdominal cramps, weight loss.

\section{Anamnesis morbi}

Patient developed all symptoms five years ago when diarrhea with blood and fatigue occurred. The ulcerative colitis was diagnosed. The patient was prescribed drug treatment with mesalazine with marked efficacy. Further the patient refused treatment and supervision by gastroenterologist. The health status was worsened in October 2017 when lower abdominal pain, diarrhea with blood occurred. The patient was admitted to the Kharkiv Research Institute of General and Emergency Surgery. The colonoscopy showed narrowed lumen of sigmoid colon to $8 \mathrm{~mm}$ at a distance of $30 \mathrm{~cm}$ from the anus, mucous membrane was loose, edematous, with a lot of ulcers and granulation growths, covered with fibrin and necrotic detritus. Histologically - granulation tissue, necrotic detritus and fragments of the hyperplastic mucosa of the colon with severe chronic inflammatory infiltration. The diagnosis ulcerative colitis, partial large bowel obstruction, chronic anemia was established.
The health status was slightly improved. The patient was referred to the Institute of Therapy for the purpose of clarifying the diagnosis and correction of therapy.

\section{Anamnesis vitae}

Patient denies tuberculosis, hepatitis, sexually transmitted infections, traumas, hereditary diseases. He has had an acute thrombosis and necrosis of hemorrhoidal nodes. He does not have any surgical intervention. Allergic history is negative. The patient denies smoking and alcohol abuse.

\section{Objective examination}

Patient's conciseness is clear, general condition is of moderate severity, posture is active. Patient is orientated in place, time and his personality. $\mathrm{He}$ has an asthenic constitution and low nutrient intake. Skin and visible mucous membranes are pale. Thyroid gland is not enlarged. Peripheral lymph nodes are non-palpable. Respiratory rate is 18 per minute. Lung percussion reveals resonant sounds. Vesicular breathing was auscultated. Heart borders are not shifted. Heart auscultation: heart rhythm is regular, heart sounds are muffled. Pulse rate is 83 beats per minute. BP is $100 / 70 \mathrm{~mm} \mathrm{Hg}$ on both arms. Abdomen is slightly inflated, participates in breathing. Palpation is painful in the left iliac region. Blumberg sign is negative. Liver and spleen are non-palpable. Pasternatsky's sign is negative on both sides. Ankle edemas are present.

\section{Laboratory and instrumental tests}

In $\underline{C B C} \quad(\mathbf{0 3 . 1 0 . 1 7 )}$ low levels of erythrocytes $\left(3,09^{*} 10^{12} / \mathrm{L}\right.$; normal range $\left.4,00-5,00 * 10^{12} / \mathrm{L}\right), \quad$ hemoglobin $(82 \mathrm{~g} / \mathrm{L}$; normal range $130-160 \mathrm{~g} / \mathrm{L}$ ); low levels of mean corpuscular hemoglobin concentration (MCHC) (301 g/L, normal range is 310 $355 \mathrm{~g} / \mathrm{L}$ ), elevated levels of platelets (539, $\left.5 * 10^{9} 1\right)$, hematocrit $(27,2 \%$; normal range 35-55\%); normal mean corpuscular volume (MCV) (88,0 fL; normal range 80,0$100,0 \mathrm{fL})$, normal mean corpuscular hemoglobin $(\mathrm{MCH})$ (26,5 pg; normal rage 26,0-34,0 pg), white blood cells (WBC) are normal 5,2* $10^{9} / \mathrm{L}$ (normal range 4,0 $9,0^{*} 10^{9} / \mathrm{L}$ ), elevated levels of lymphocytes (48\%) and erythrocytes sedimentation rate (ESR) $-48 \mathrm{~mm} / \mathrm{h}$. In CBC the anisocytosis and poikilocytosis are marked. 
The possible causes of anemia in CD include intestinal blood loss which can result in iron deficiency anemia; also anemia of chronic disease due to chronic inflammation and megaloblastic anemia secondary to vitamin B12 and folate malabsorption in chronically inflamed ileum may be present. Unlike the other causes, vitamin B12 and folate deficiencies lead to macrocytic anemia [2].

In patient's $\mathrm{CBC}$ hypochromic normocytic anemia and features of iron deficient are present.

Inflammatory markers such as elevated ESR, thrombocytosis are also present in CBC.

Urinalysis (03.10.17): no abnormalities were found.

Blood biochemistry (03.10.17): elevated levels of very-low-density lipoproteins (VLDL) $(0,74 \mathrm{mmol} / \mathrm{L}$, normal range is 0 , $25-0,72 \mathrm{mmol} / \mathrm{L})$ and C-reactive protein (CRP) $(192 \mathrm{mg} / \mathrm{l}$; normal range is $0-6 \mathrm{mg} / \mathrm{l})$, decreased level of total protein $(52 \mathrm{~g} / \mathrm{l}$, normal range is $65-85 \mathrm{~g} / \mathrm{l}$ ) and blood albumin (29, $0 \%$; normal range is $56,6-66,8 \%$ ); increased levels of alfa-2 globulin (12,4\%; normal range is $6,9-10,5 \%$ ), beta globulin (21,2\%; normal range is $7,3-12,5 \%)$ and gamma globulin $(34,4 \%$; normal range is 12,8-19,0\%).

Liver and kidney function tests are unremarkable.

Inflammatory marker such as markedly elevated CRP is present.

Hypoproteinemia and hypoalbuminemia can be attributed to malabsorption. Syndrome of malabsorption which develops due to a malfunction of the intestinal wall or intraluminal disorder (e.g., enzyme deficiency) those results in the insufficient absorption of breakdown products. Malabsorption can affect macronutrients (eg, proteins, carbohydrates, fats), micronutrients (eg, vitamins, minerals), or both. Signs and symptoms depend on the location of the defect and can include diarrhea, steatorrhea, abdominal distention, flatulence, weight loss, anemia, vitamin deficiencies [2].

Coprogram (03.10.17): unformed stool, feces test for latent blood was weakly positive, a large amount of starch grains, a slightly elevated amount of indigestible fiber, leukocytes, erythrocytes, mucus.
Bacteriological examination of stool (04.10.17): Bifidobacterium and lactobacilli were found.

Stool samples are routinely collected in $\mathrm{CD}$ patients to test the presence of WBCs, routine pathogens, ova, parasites, and Clostridium difficile toxin to rule out superinfections during relapses and before the initiation of immunomodulatory therapy [3].

Echocardiography (13.10.17): ejection fraction (EF) is $65 \%$. Contractility function is preserved. The heart chambers are not dilated. The walls of the aorta are compacted.

Abdominal ultrasonography (04.10.17): sings of chronic pancreatitis, chronic cholecystitis with bile congestion and sludges.

Video colonoscopy (10.10.17): the examination was available up to the proximal third of the transverse colon. There is a typical endoscopic picture of Crohn's disease with high activity and total lesion of the large intestine. The acute combined hemorrhoids and the acute anal fissure are present.

Endoscopy confirms the diagnosis, assesses the extent of the disease, helps to differentiate $\mathrm{CD}$ from other diseases (e.g., UC, peptic ulcers, etc.), and may also be used as a therapeutic tool (e.g., dilatation of ducts, intestinal loops).

Typical findings of ileocolonoscopy include segmental/discontinuous pattern of involvement. Macroscopic findings specific for $\mathrm{CD}$ are the following: linear ulcers (snail trails); other aphthous hemorrhagic mucosa defects (pinpoint lesions); cobblestone sign (characteristic appearance of the mucosa is inflamed sections followed by deep ulcerations that resemble uneven cobblestones); fissures and fistulas. Erythema and transmural inflammation are also present [2].

Computer tomography (CT) of thoracic, abdomen organs and retroperitoneal space with contrasting (05.10.17): The CT data for the neoplastic process are not revealed. The changes in the intestine are probably due to colitis. A concrement of the left kidney is present. Cardiomegaly and small hydropericardium are found.

Kidney stones and gallstones (bile sludge in our patient) can be contributed to such specific intestinal manifestation as disturbed reabsorption of bile acids and bile acid malabsorption. Bile acids emulgate fat and 
therefore help in the digestion of fats. If their enterohepatic circulation is disturbed by faulty reabsorption, the liver reacts by producing more bile acids from cholesterol. If this mechanism is exhausted (decompensated bile acid malabsorption), the lack of bile acids results in diarrhea, steatorrhea, deficiencies in fat-soluble vitamins and gallstones and kidney stone formation. Mechanism of gallstones increasingly is related to the loss of the emulgator bile acid. As a result, the cholesterol cannot be dissolved sufficiently and precipitates. Mechanism of kidney stone formation is related to the disrupted creation of calcium oxalate due to an excess of free fatty acids caused by a deficiency in bile acids. Calcium preferably binds to the free fatty acids, leading to increased absorption of free oxalate and a higher risk of kidney stones. Normally, oxalate and calcium combine in the intestines to form an insoluble salt (calcium oxalate) that is excreted in the feces [2].

ECG (13.10.17): sinus rhythm with heart rate 75 beats per minute, left and right ventricular hypertrophy with severe left ventricular overload. Left anterior fascicular block.

Consultation of cardiologist (13.10.17): Essential arterial hypertension II stage, 1st degree, low total cardiovascular risk.

\section{Additional methods of investigation which may be ordered}

Serum levels of iron, total iron binding capacity, transferrin, ferritin, vitamin B12 and folate can be used for clarification of the type anemia and evaluation of malnutrition and some nutrient deficiencies.

Anti-Saccharomyces cerevisiae antibodies are antibodies directed at components of the cell wall of the yeast Saccharomyces cerevisiae. The presence of these antibodies is associated with chronic inflammatory bowel disease, most strongly CD [4-5].

Possible detection of fecal calprotectin and/or lactoferrin. Lactoferrin and fecal calprotectin are neutrophil-derived proteins which are used as specific surrogate markers of intestinal inflammation. Lactotransferrin is an iron-binding protein produced by neutrophils and found in secretory fluids and mucosal barriers that inhibits microbial growth. These parameters are commonly used to differentiate between $\mathrm{CD}$ and other non-infectious causes of gastrointestinal disorders. In addition, they are used to monitor the course of the disease or to confirm recurrent episodes. These fecal biomarkers may help avoid the need for otherwise invasive measures that assess intestinal inflammation [6].

Esophagogastroduodenoscopy also should be considered to assess the possible involvement of the esophagus, stomach, and duodenum and is useful in differential diagnosis between $\mathrm{CD}$ and UC. Findings specific for upper GI tract affection in CD include aphthae on mucosa [7].

\section{Differential diagnoses}

UC

Infectious gastroenteritis

Irritable bowel syndrome

Colorectal malignancy

Diverticulitis

Non-infectious colitis (post-radiation, drug-induced, ischemic etc.)

Gastrointestinal tuberculosis

Acute appendicitis

\section{Clinical diagnosis}

Crohn's disease of the colon, stenosing form with high activity, hormone-dependent, with extraintestinal manifestations (chronic pancreatitis with exocrine insufficiency, chronic cholecystitis with hypokinetic dyskinesia of the gallbladder, biliary sludge). Left kidney stone. Anemia of chronic disease, moderate severity

Essential arterial hypertension II stage, 1st degree, low total cardiovascular risk. HF II FC

\section{Treatment}

General approach includes smoking cessation; lactose-free diet in case of secondary lactose intolerance which is present in approximately one third of cases; in the case of malabsorption syndrome appropriate replacement of vitamins, calories, protein, zinc, calcium and other nutrients is considered. Treatment bile acid diarrhea includes administration of ion-exchange resins to bind bile acids (e.g., cholestyramine).

During acute episodes recommendations to avoid dietary fibers should be given and parenteral nutrition can be prescribed.

Our patient received drug therapy: reosorbilact solution $200,0 \mathrm{ml}$ during four 
days, then infesol solution $500,0 \mathrm{ml}$ and $5 \%$ glucose solution with ascorbic acid $4,0 \mathrm{ml}$ during three days, $20 \%$ human albumin solution $100,0 \mathrm{ml}$ one day, methylprednisolone $32 \mathrm{mg} /$ day during first seven days then dose was reduced to $28 \mathrm{mg} /$ day, mesalazine $300 \mathrm{mg} /$ day, enalapril $10 \mathrm{mg} /$ day, hydrochlorothiazide $12,5 \mathrm{mg} /$ day Patient condition was improved: the frequency of defecations was decreased, blood in feces disappeared. Nevertheless fatigue and ankle edemas were still present.

After discharge patient received recommendation to follow-up low-fiber, low-fat and low-lactose diet and take plenty of water. Drug therapy includes methylprednisolone $28 \mathrm{mg} /$ day 2 weeks then weekly dose reduction by $4 \mathrm{mg}$. mesalazine $800 \mathrm{mg}$ 4 times per day, enalapril $10 \mathrm{mg} /$ day, hydrochlorothiazide $12,5 \mathrm{mg}$ /day.

\section{Check-ups}

Clinical curse of $\mathrm{CD}$ is associated with significantly increased risk of colorectal carcinoma and/or frequent relapses of the disease, that's why close following-up with regular endoscopy is of great importance.

\section{Prognosis}

Because the entire gastrointestinal tract is typically affected in $\mathrm{CD}$, it is non-curable disease. The goal of treatment of CD is thus to slow the progression of the disease, avoid recurrence of inflammatory episodes and prevent complications which are extremely common in the absence of optimal treatment. Life expectancy is normal and quality of life may be satisfactory with aggressive evidencebased treatment. Majority of patients (approximately $70 \%$ ) requires surgical operations due to complications within 15 years of their onset [7].

\section{REFERENCES}

1. Fakhoury M. Inflammatory bowel disease: clinical aspects and treatments / M. Fakhoury, R. Negrulj, A. Mooranian, H. Al-Salami // Journal of Inflammation Research. - 2014. - No. 7. - p. 113-120.

2. Ha F. Crohn's disease: a clinical update / F. Ha, H. Khalil // Therap. Adv. Gastroenterol. - 2015. No 8(6). - p. 352-359.

3. Takeuchi K. Prevalence and mechanism of nonsteroidal anti-inflammatory drug-induced clinical relapse in patients with inflammatory bowel disease / K. Takeuchi, S. Smale, P. Premchand, et al.] // Clin Gastroenterol Hepatol. - 2006. - No 4(2). - p. 196-202.

4. Cambridge G. Anti-neutrophil antibodies in inflammatory bowel disease: prevalence and diagnostic role /G. Cambridge, D. S. Rampton, T. R. J. Stevens et al] // Gut. - 1992. - No 33(5). - p. 668-674.

5. Lecis P. p-ANCA and ASCA antibodies in the differential diagnosis between ulcerative rectocolitis and Crohn's disease / P. Lecis, B. Germanà, N. Papa et al] // Recenti progressi in medicina. - 2002. No 93(5). - p. 308-313.

6. Di Ruscio M. Surrogate Fecal Biomarkers in Inflammatory Bowel Disease: Rivals or Complementary Tools of Fecal Calprotectin? // M. Di Ruscio, F. Vernia, A. Ciccone et al.] // Inflamm. Bowel. Dis. - 2017. - No 24(1). - p. 78-92.

7. Al-Bawardy B. Endoscopic and Radiographic Assessment of Crohn's Disease / B. Al-Beardy, S. L. Hansel, J. L. Fiddler, et al.] // Gastroenterol Clin North Am. - 2017. - No 46(3). - p. 493-513. 